\title{
A Macrodinâmica Social Brasileira: Mudanças, Continuidades e Desafios*
}

\author{
Eduardo Salomão Condé \\ Francisco Fonseca ${ }^{2}$ \\ ${ }^{1}$ Universidade Federal de Juiz de Fora (UFJF), Juiz de Fora, MG, Brasil. E-mail: \\ eduardosconde@gmail.com. \\ ${ }^{2}$ Escola de Administração de Empresas de São Paulo (Easp), da Fundação Getulio Vargas \\ (FGV), São Paulo, SP, Brasil e Pontifícia Universidade Católica de São Paulo (PUC-SP). \\ E-mail: franciscocpfonseca@gmail.com.
}

\section{INTRODUÇÃO E PROBLEMATIZAÇÃO}

\begin{abstract}
o final da primeira década do século XXI, o cenário econômico A oscilava entre crise e controvérsia. De forma similar à última parte da década de 1990, uma grande crise, desencadeada pelo crash de 2008 , criou ambiente de enorme incerteza. Quanto aos atores dessa ordem internacional, a China permanece como um dos grandes motores da economia mundial; os Estados Unidos, por sua força e apesar de a crise ter irrompido desde sua economia, continuam referência obrigatória na cena internacional; e a União Europeia, ainda que seja um importante player internacional, permanece entre os dilemas de sua unificação e uma posição acessória no xadrez mundial, agravada por suas próprias respostas conservadoras à crise de 2008. Já a América Latina, com graus variados, parece oscilar entre a conservação e a mudança.
\end{abstract}

Quanto ao Brasil, vem recebendo substantiva atenção no cenário internacional, em diversos aspectos. Não porque tenha resolvido suas históricas questões relativas à desigualdade - embora as esteja amenizando-ou aos problemas de infraestrutura. O destaque advém, para além dos vários resultados concretos, de ações continuadas apontarem para um rumo: a convivência entre soluções ortodoxas em política monetá-

* Os autores agradecem a participação dos pesquisadores William R. A. Ponte e Juliane Rocha Lara na atualização e revisão dos dados e indicadores citados neste artigo.

DADOS - Revista de Ciências Sociais, Rio de Janeiro, vol. 58, no1, 2015, pp. 151 a 185. 
ria e preocupações objetivas quanto ao papel do Estado e sua capacidade de investimento, entendido tanto como indutor e promotor de ações regulatórias e de intervenção direta, quanto como formulador de políticas sociais e setoriais.

Como exemplos, destaque-se o aumento da participação brasileira no comércio mundial, particularmente no mercado de commodities (o que não deixa de ser controverso tendo em vista a diminuição da participação nas exportações de produtos industriais, de maior valor agregado, mas que não é objeto deste artigo); a diversificação dos seus mercados (priorização à América Latina e ao Mercosul, novas relações com o Oriente Médio e África, entre outros), o que implica nova visão acerca das relações internacionais; papel mais ativo na própria internacionalização econômica, para além, portanto, de sua histórica inserção "passiva", entendida esta como dependência quase exclusiva e subalterna, quanto ao comércio internacional, aos mercados dos EUA e Europa ${ }^{1}$, assim como protagonismo político no G-20; o potencial energético, notadamente petróleo e biocombustíveis; e a rápida resposta à crise mundial de 2008, pela via da combinação de crédito, redução de impostos de bens de consumo duráveis, investimento estatal e políticas compensatórias e setoriais.

Essas ações credenciaram o Brasil à posição de protagonismo num mundo relativamente instável diante dos riscos econômicos (notadamente dúvidas quanto à retomada do crescimento, as crises de balanço de pagamentos, a confiança dos agentes) e políticos (tensões desafiadoras no cenário internacional, reposicionamentos geopolíticos e geoeconômicos, a ascensão particular da China, tensões militares e regimes políticos desafiadores do establishment internacional) ${ }^{2}$.

Observe-se, contudo, que uma dimensão importante da atenção ao Brasil deriva do movimento de suas decisões políticas e econômicas. Nesse sentido, embora o país venha obtendo notável presença internacional, este artigo procura analisar dimensões endógenas da realidade brasileira, olhando-se para o cenário mundial como contexto, notadamente o econômico. O estudo pretende indicar dados sobre a macrodinâmica da sociedade brasileira, analisando-se indicadores desde 1995, mas sem perder de vista o contexto internacional, uma vez que cenário importante à tomada de decisões nacionais, internas. Não se trata do balanço de períodos presidenciais, e sim a tentativa reflexiva de compreensão da macrodinâmica social, especificamente o mercado de tra- 
balho e indicadores sociais relevantes que auxiliem na tarefa de analisar tendências quanto às transformações efetivas na estrutura social e econômica brasileira, daí derivando seus desafios ${ }^{3}$.

Note-se que o que se entende por macrodinâmica social, que estaria em movimento particularmente desde o início dos anos 2000, implica um conjunto de variáveis - tais como ampliação de vagas de trabalho, formal e informal; renda do trabalho e transferências governamentais distintas, como bolsas e, de certa forma, o próprio crédito; o papel do salário mínimo e da Previdência Social; e elementos macroeconômicos impactantes na vida social - que, vistas de forma conjugada, organizam um quadro representativo de mudanças na sociedade brasileira, que estaria em movimento. Nunca é demais ressaltar que mudanças convivem com permanências e, dependendo do aspecto observado, com recuos. No entanto, a hipótese aqui perseguida refere-se ao vetor de mudanças - daí a ideia de dinamismo - que estaria transformando a sociedade brasileira, apesar das contradições inerentes, como é sempre bom enfatizar.

Daí não ser objetivo deste texto o aprofundamento de cada variável observada, tais como os movimentos e contramovimentos, com respectivas literaturas específicas, acerca do trabalho, do emprego e das ocupações, formais e informais; da renda advinda do trabalho; do papel do Estado em relação ao crédito, ao salário mínimo, às bolsas e à Previdência; dos aspectos macroeconômicos, como o crescimento do produto interno bruto (PIB), a dinâmica das exportações; e do cenário político e particularmente econômico internacional; entre outros. O aprofundamento de todas essas variáveis, e de subvariáveis que advêm delas, seria simplesmente impossível tendo em vista os parâmetros de um artigo.

Dessa forma, é justamente o olhar em perspectiva, panorâmico, sem, contudo, perder densidade analítica - com vistas justamente a promover a articulação dessas variáveis, observando sua organicidade e, consequentemente, seu vetor - que este artigo objetiva. Em outras palavras, pretende-se analisar variáveis decisivas ao mundo social, numa perspectiva macro (entendida tanto no sentido de composição sistêmica de informações como das balizas da economia política), cujo foco é a compreensão do movimento, aqui pressuposto, da sociedade brasileira rumo à construção de bases universais, inclusivas e igualitárias no que tange ao tecido social.

DADOS - Revista de Ciências Sociais, Rio de Janeiro, vol. 58, nº 1, 2015 


\section{TRABALHO E EMPREGO: INDICADORES DE MUDANÇA}

Retomando as reflexões típicas dos anos 1990 sobre o mercado de trabalho no Brasil, deve-se destacar a perspectiva um tanto pessimista das análises. De um lado, a tese conservadora do sufocamento do mercado, pois asfixiado por leis excessivas e rigidez (Pastore, 1998; Camargo, 1996); de outro, a crônica incapacidade em gerar empregos derivada da "terceira revolução industrial" (Mattoso, 1995) ou do "fim dos empregos" e os desafios da automação (Rifkin, 2004). Outra vertente apontava para a questão do "capital humano", decorrente da escolarização precária e da formação escolar deficiente. E ainda pode-se verificar a versão, mais à esquerda, em que o capitalismo em mutação forçaria alterações significativas aos trabalhadores, ameaçando suas conquistas (Antunes, 1995); assim como apontam "a crise da centralidade do trabalho" (Offe, 1991). Em todas as perspectivas, que por vezes se cruzam, o trabalho é colocado na berlinda, ainda que os diagnósticos sejam muito distintos (inclusive os dos autores citados), bem como as soluções propostas. Essas perspectivas demonstram, neste texto, os termos do debate ao qual o Brasil esteve presente e pode posteriormente, por meio de decisões políticas e de economia política, aplicar políticas públicas nos mais diversos setores sociais que desanuviaram esse ambiente pessimista, conforme os números demonstram no Gráfico 1:

Como se observa, na década e meia compreendida entre 1995 e 2010 o gasto social federal (GSF) cresceu 4,3\% do PIB e $172 \%$ em valores reais,

Gráfico 1

Gasto Social Federal por Área de Atuação (1995/2002/2010)

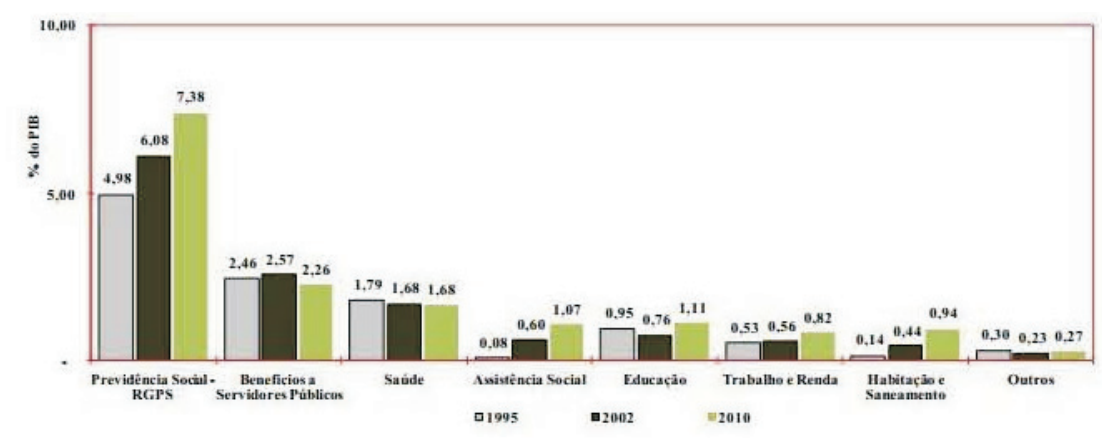

Fonte: SIAFI/SIDOR. Elaboração Disoc/Ipea. Disponível em http:/ /www.ipea.gov.br/portal/images/stories/PDFs/nota_tecnica/120904_notatecnicadisoc09_apresentacao.pdf. Acesso em $15 / 5 / 2013$. 
Gráfico 2

Trajetória do Gasto Social Federal 1995-2010

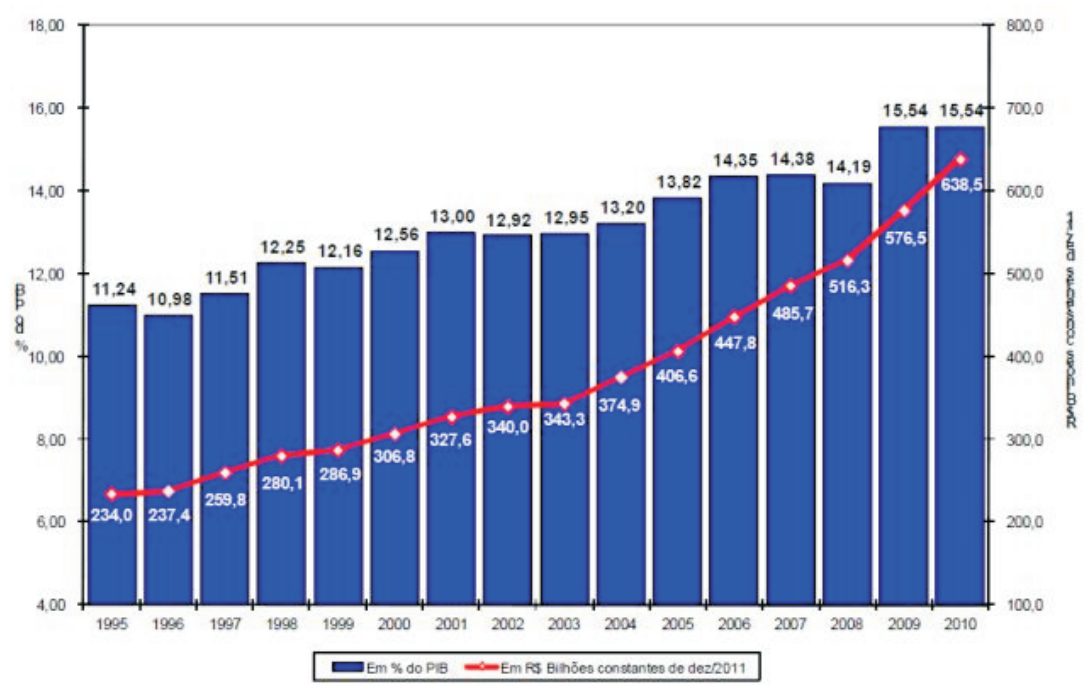

Fonte: SIAFI/SIDOR. Elaboração: Disoc/Ipea. Disponível em http:/ / www.ipea.gov.br/portal/images/stories/PDFs/nota_tecnica/120904_notatecnicadisoc09_apresentacao.pdf. Acesso em $2 / 5 / 2014$.

acima da inflação (índice nacional de preços ao consumidor amplo IPCA). De 1995 a 2003, o GSF cresceu 1,7\% do PIB, e de 2004 a 2010 cresceu 2,3\% do PIB. De 1995 a 2010 o GSF per capita cresceu cerca de 120\% acima da inflação (IPCA), como mostra o Gráfico 2:

Tendo em vista essas perspectivas, observa-se que, transcorrida pouco mais de uma década, a crise do mercado de trabalho não se configurou; ao contrário. Ainda que seja necessário refinar os dados, aprofundando-os ao nível das diferentes atividades, dos rendimentos médios por atividade, nível de escolaridade e distribuição funcional, a agenda assentada na debacle do trabalho necessita ser repensada, tomando-se como referência de análise o Brasil ${ }^{4}$. Afinal, o nível de atividade apresenta tendência clara, como pode ser observado no Gráfico 3, bem como a queda no desemprego (Gráfico 4).

Observe-se que a taxa de ocupação, expressa pela relação entre os ocupados e a população economicamente ativa (PEA), oscilou entre $87 \%$ e $93,8 \%$ entre 2002 e 2008, ainda com leve tendência de alta (dados de 2010). A elevada taxa de ocupação tem seu correlato também na redução dos indicadores de desemprego. Entre março de2002 e setembro

DADOS - Revista de Ciências Sociais, Rio de Janeiro, vol. 58, nº 1, 2015 


\section{Gráfico 3}

Taxa de Ocupação (\%)

(Brasil, 2002-2010)

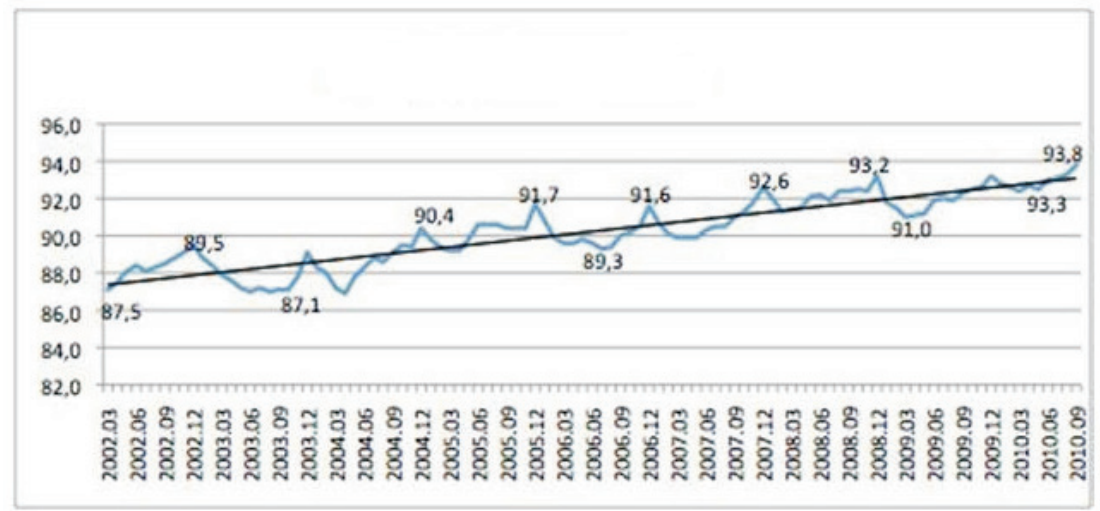

Fonte: Instituto Brasileiro de Geografia e Estatística (IBGE), vários anos. Elaboração própria.

\section{Gráfico 4}

Desemprego (\%)

(Brasil, 2002-2010)

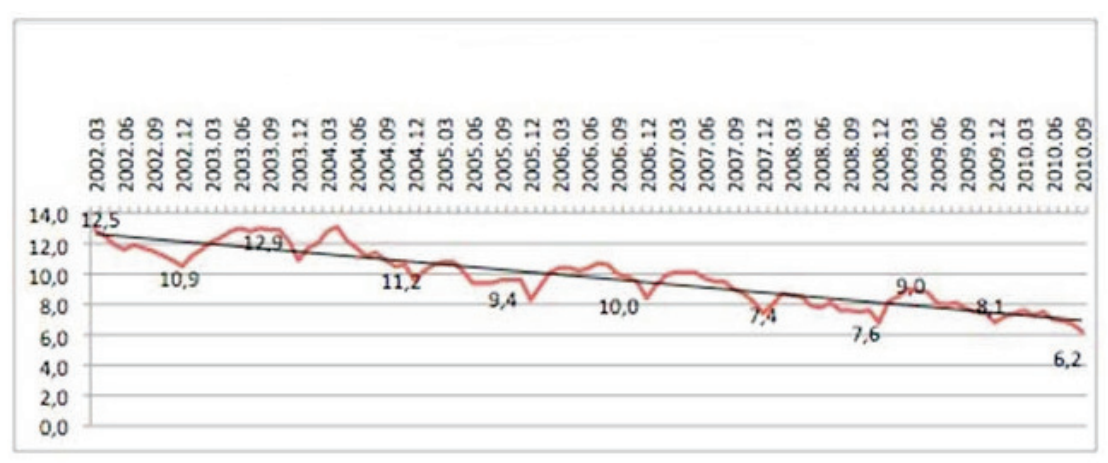

Fonte: IBGE, vários anos. Elaboração própria.

de 2010 o nível de desemprego caiu pela metade, sendo que a partir de março de 2009 o indicador decresceu de forma praticamente ininterrupta até o patamar de 6,2\%, em setembro de 2010.

Se considerarmos o tipo de vínculo (ou a ausência de), também parece invertida a tendência de desmonte do mercado de trabalho. Como aludido, um dos aspectos mais notáveis da literatura, particularmente a equivalente à chamada "rigidez" deste mercado, referia-se à incapacidade de admissão pelo excesso de regulação e pela tendência à infor- 
Gráfico 5

Emprego por Tipo (\%)

(Brasil, 2002-2010)

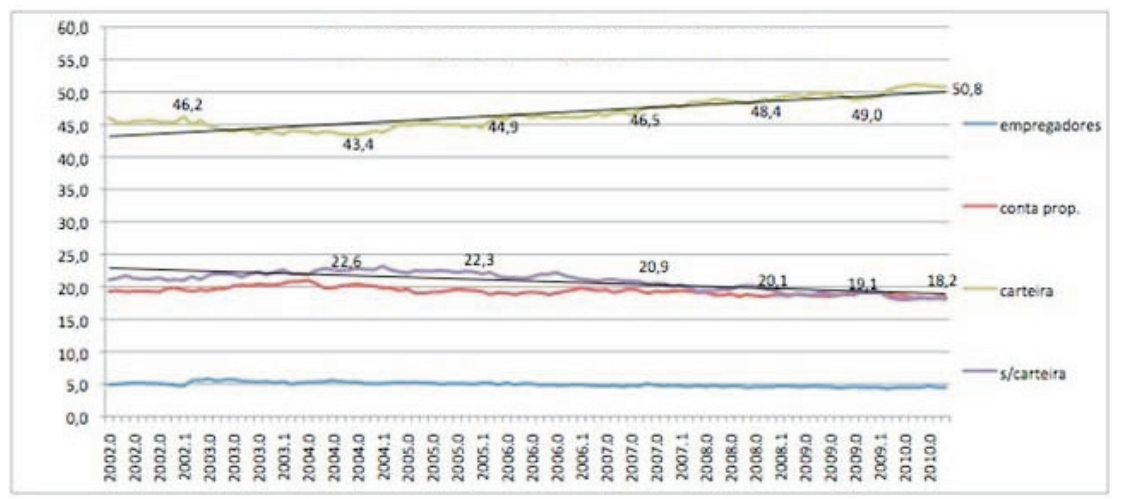

Fonte: IBGE, vários anos. Elaboração própria

malidade, dados os desestímulos da "extorsiva" carga tributária e complexidade legal.

O Gráfico 5 indica números de empregados com registro e sem registro, com as duas tendências. Verifica-se o movimento oposto entre ambas as categorias, revelando evolução crescente entre os empregados registrados. Observe-se, contudo, que não se está considerando a qualidade específica dos empregos, uma vez que sua geração pode ocorrer em setores demandadores de mão de obra menos qualificada, como aparentemente é o caso. Deve-se ressaltar, como se observa neste artigo, que a taxa de ocupação, sobretudo a formal, se eleva com o crescimento do PIB.

Um dado interessante é o movimento em torno da informalidade. $\mathrm{O}$ Gráfico 6 revela uma indicação importante, particularmente porque se utiliza de uma série mais longa ${ }^{5}$.

Nas áreas urbanas não metropolitanas, a relativa estabilidade deu lugar à tendência de queda visível. Em 1995 havia informalidade de 64,5\%; em 2002 estava na casa dos 59\%. A partir daí, a queda foi acentuada. Já a curva para as áreas metropolitanas é diversa, uma vez que entre 1995 e 2002 a informalidade havia aumentado de $42,6 \%$ para $47,2 \%$, partindo daí para queda muito mais lenta. Tanto que a reta de tendência é estável no tempo, até com pequena elevação. Aqui reside interessante comparação para a dinâmica do "emprego" informal. Até 2002, a elevação da informalidade mostrava que a incapacidade em ge- 
Gráfico 6

Informalidade

(Brasil, 1995-2007)

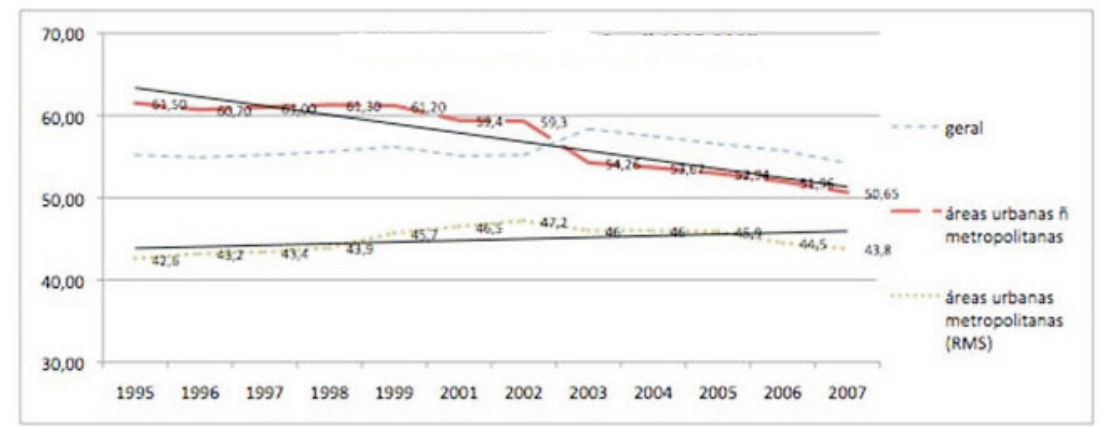

Fonte: IBGE, vários anos. Elaboração própria.

rar emprego formal não indicava que isto se devesse a qualquer rigidez estrutural, desde que comparemos este período com o posterior. A queda de quase quatro pontos entre 2002 e 2007 nas áreas metropolitanas contrasta com a queda acima de nove pontos nas áreas não metropolitanas. Neste caso, a dinâmica da formalização, intensificada a partir de 2002, teve impacto muito mais forte no conjunto do país e menos em áreas mais densamente populosas das grandes cidades. Destaque-se que o crescimento do país, importante para o crescimento das

Gráfico 7

Trajetória do Gasto Social

(1995-2010)

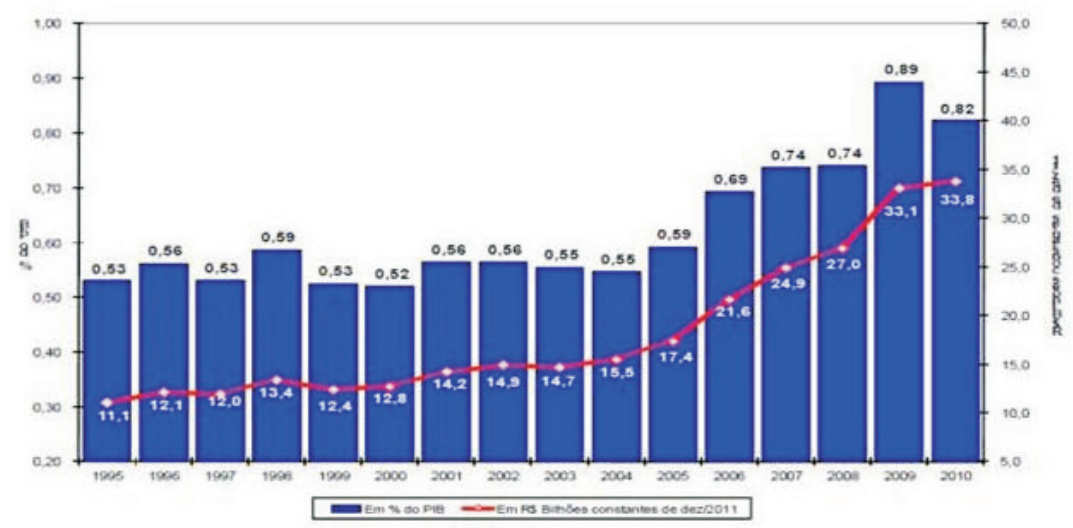

Fonte: SIAFI/SIDOR e Ipeadata. Elaboração: Disoc/Ipea. Disponível em: http://www.ipea.gov. $\mathrm{br} /$ portal/images/stories/PDFs / nota_tecnica/120904_notatecnicadisoc09_apresentacao.pdf. Acesso em 20/5/2013. 
taxas de emprego como um todo, e formal em particular, não foi concentrado nas regiões mais dinâmicas, mas tendeu a formalizar mais emprego onde antes isso acontecia menos, ou seja, em regiões mais periféricas. Com dados mais recentes, de 2013, a tendência de redução da informalidade continua: nas regiões não metropolitanas atingiu $43,1 \%$, e nas metropolitanas a queda foi de $31,9 \%$. Na média, o Brasil atingiu queda de $39,3 \%{ }^{6}$.

Por outro lado, a maior lentidão na queda dos trabalhadores informais em regiões metropolitanas indica que há um longo caminho a percorrer. Afinal, outros determinantes estruturais interferem nessa dinâmica, tais como a necessidade de maior escolarização; o aumento da capacidade produtiva, particularmente no setor industrial; os instrumentos de crédito para investimento com condições competitivas de captação; a qualificação profissional; e a desoneração da folha, paralelamente aos impactos positivos dos programas sociais.

Os níveis de crescimento representam estimulante poderoso, capazes de reduzir contingentes de mão de obra ociosa, saindo-se da inércia da etapa "lenta" do ciclo. A linha de variação é fortemente dispersa, como se observa no Gráfico 8:

\section{Gráfico 8}

Variação Anual PIB (\%)

(Brasil, 1994-2010)

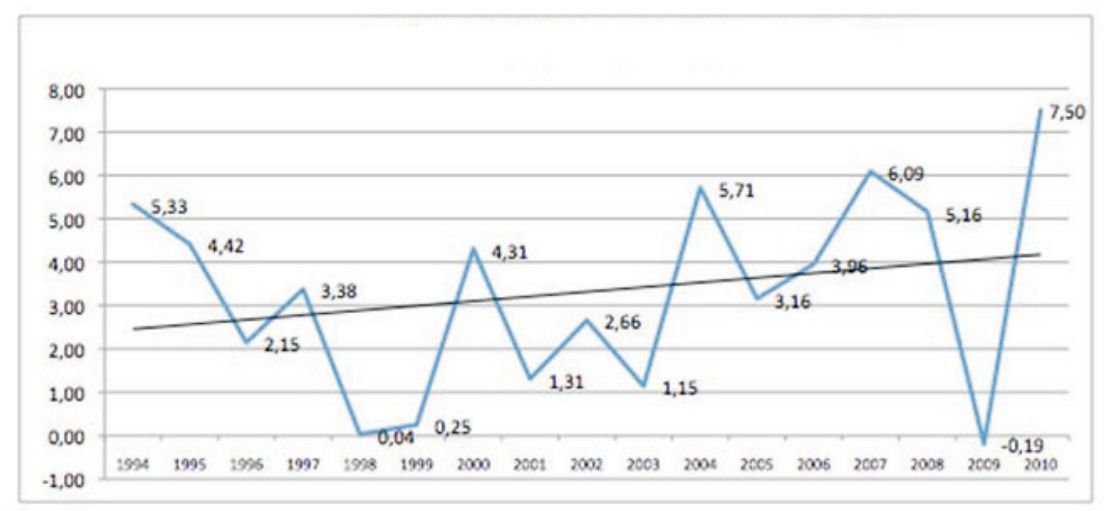

Fonte: Instituto de Pesquisa Econômica Aplicada (IPEADATA). Elaboração própria. Dado para 2010 é estimado.

A tendência indica propensão de crescimento entre 1994 e 2010, ainda que leve e muito variante. Como reflexo das estratégias de estabilização dos anos 1990, entre 1994 e 1996 e entre 1997 e 1999 o resultado é de-

DADOS - Revista de Ciências Sociais, Rio de Janeiro, vol. 58, nº 1, 2015 
cepcionante, agravado ainda pela crise internacional de 1997-1998. A estupenda redução ocorrida em 1998 foi tão forte que a retomada seguinte era esperada (em 2000), inclusive fortalecida pelas alterações na política cambial, no início do segundo governo de Fernando Henrique Cardoso. Os dois primeiros anos do governo Luiz de Inácio Lula da Silva não foram melhores, pois houve ajustes duros do novo governo, seguindo-se a mesma cartilha do anterior. O período Palocci no Ministério da Fazenda mantinha concepção de aperto fiscal e monetário idêntico ao do período Cardoso e reduziu ainda mais o crescimento em 2003, mas o período seguinte, apesar da elevada taxa de juros, foi de grande salto no crescimento. A crise do chamado "mensalão", a queda de Palocci e a reorientação dada à política econômica - progressivamente mais expansionista, creditícia, com investimento estatal e estímulos setoriais -iniciou trajetória ascendente nos anos de 2005 a 2007 ${ }^{7}$, e, de certa forma 2008, mas que, como resultado da crise internacional, declinou novamente ${ }^{8}$.

Observe-se a relação entre o crescimento do PIB e o desemprego, no Gráfico 9:

\section{Gráfico 9}

Variação do PIB e do Desemprego (\%)

(Brasil, 2000-1010)

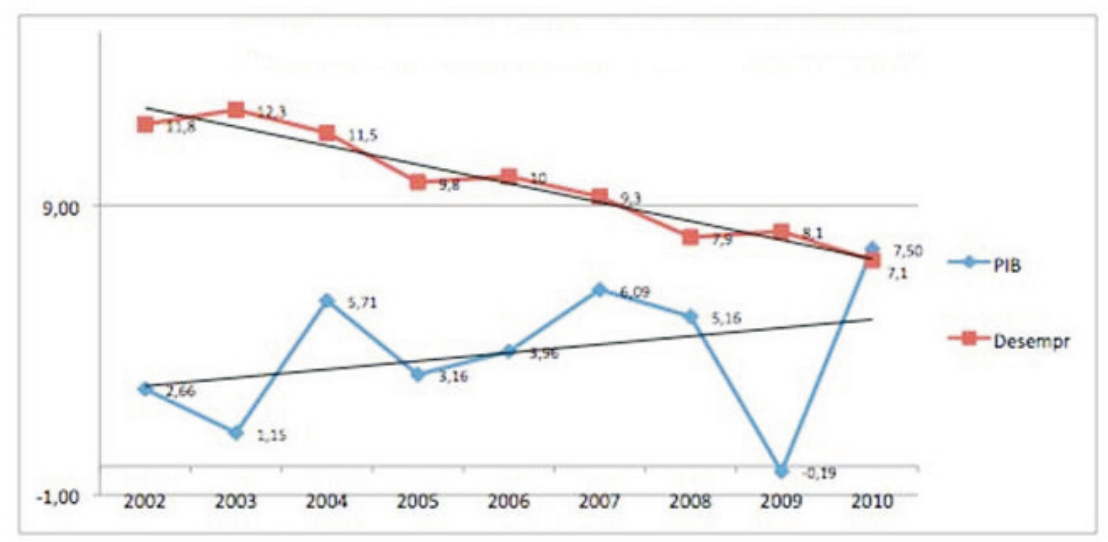

Fonte: IPEADATA e IBGE (vários anos). Elaboração própria. Dados do desemprego médio do ano a partir de dados mês a mês. PIB 2010 é estimado.

As linhas que apontam as tendências são opostas, mas como há indiscutível crescimento do PIB, a redução do desemprego é previsível. Há de se observar que a crise em 2008/2009 não provocou aumento geral 
na taxa de desemprego, antes o contrário. As alternativas anticíclicas adotadas em 2008 (e principalmente em 2009) mantiveram a atividade mais geral do emprego e estabilizaram as "perdas". O aumento do investimento (com o suporte de crédito), as desonerações tributárias (Imposto Sobre Produtos Industrializados - IPI e Imposto sobre Circulação de Mercadorias e Serviços - ICMS da "linha branca") e o mercado interno garantiram no mínimo o PIB "empatado" em zero e o desemprego estável. Ainda que a curva do PIB permaneça em formato "errático", persiste tendência de alta, com a notável exceção de 2009, o que vem ao encontro da tese de que o crescimento é um indutor de emprego, embora não o único fator. Dada a propalada "crise do emprego", conforme debatida por parcela importante da literatura sobre reestruturação produtiva e sua sinergia com a questão da flexibilização do modo de produção (pós-fordista), parecia improvável que houvesse aumento do emprego, ainda mais o formal. Passada uma década, o desemprego recuou para quase $7 \%$ em 2010. Já em 2013, a taxa de desemprego atingiu 4,6\% mantendo a tendência de queda 9

Quadro 1

Evolução Anual PIB e Desemprego

(1995-2013)

\begin{tabular}{|c|c|c|}
\hline Ano & PIB & Desemprego \\
\hline 1995 & 4,42 & 4,65 \\
1996 & 2,15 & 5,43 \\
1997 & 3,38 & 5,67 \\
1998 & 0,04 & 7,60 \\
1999 & 0,25 & 7,56 \\
2000 & 4,31 & 7,14 \\
2001 & 1,31 & 7,50 \\
2002 & 2,66 & 11,80 \\
2003 & 1,15 & 12,30 \\
2004 & 5,71 & 11,50 \\
2005 & 3,16 & 9,80 \\
2006 & 3,96 & 10,00 \\
2007 & 6,09 & 9,30 \\
2008 & 5,16 & 7,90 \\
2009 & $-0,19$ & 8,10 \\
2010 & 7,50 & 7,10 \\
2011 & 2,70 & 4,70 \\
2012 & 1,00 & 4,60 \\
2013 & 2,30 & 4,30 \\
\hline
\end{tabular}

Fonte: IBGE, Elaboração própria. 
Com o aumento do emprego formal e a redução da informalidade, o mercado teria se tornado menos "rígido"? Aparentemente não, pois não houve alteração capaz de decisivamente mudar os processos formais e legais relativos ao mercado de trabalho. O que mudou, em verdade, foi a ação mais efetiva do Estado pela via ativa de estímulo setorial e de alavancas (creditícias e tributárias, entre outras) ao ciclo virtuoso do consumo/produção, paralelamente à redistribuição "estrutural" da renda por meio do Sistema Único de Assistência Social e da Previdência Social, que, dessa forma, criam colchões protetores às crises e mantêm o consumo estável num patamar mínimo.

É possível, contudo, interpretar alternativamente o fenômeno do emprego no Brasil, na medida em que se afirma ser o aumento do emprego formal não apenas sazonal, portanto não sustentável ao longo do tempo, como principalmente um fenômeno em que estruturalmente a ocupação informal substitui - na lógica do desemprego estrutural tecnológico - a formalização do emprego. Em outras palavras, o estoque de empregos formais seria estrutural e progressivamente decrescente, tal como no exemplo da indústria automobilística, que nos anos 1940 empregava dez vezes mais trabalhadores para produzir um número muito inferior de automóveis, situação que se inverte dos anos 1980 aos dias de hoje. Nessa perspectiva, apenas um inventário por meio de uma série histórica longa - por exemplo, entre os anos 1940 aos dias de hoje - poderia analisar a relação entre estoque de empregos, reais e potenciais, e empregabilidade. Mas trata-se de outra pesquisa, e de uma visão alternativa baseada na lógica do modelo de acumulação. Seja como for, o fato é que os números referentes à formalização do emprego no Brasil são claros e impactantes o suficiente para colocar em questão tanto as restrições econômicas internacionais quanto o ceticismo de parte significativa da literatura quanto ao "futuro do emprego". Com efeito, dado o cenário atual, é possível dizer que há tendência de manutenção do emprego no curto e médio prazo.

Nunca é demais reafirmar que este artigo pretende - ao rememorar os termos do debate sobre o emprego e questões afins na literatura, e ao demonstrar os números de sua ampliação recente - lançar luz na macrodinâmica brasileira recente, sem tirar conclusões acerca dos fatores estruturais relativos a questões como o estoque de empregos e outros fatores tidos como "estruturais" nas premissas, lógica e dinâmica do capitalismo contemporâneo. Somente pesquisas com esse intuito podem concluir a respeito e numa perspectiva comparada entre países e regiões. 
Gráfico 10

Inflação e Salário Mínimo

(Brasil, 2003-2010)

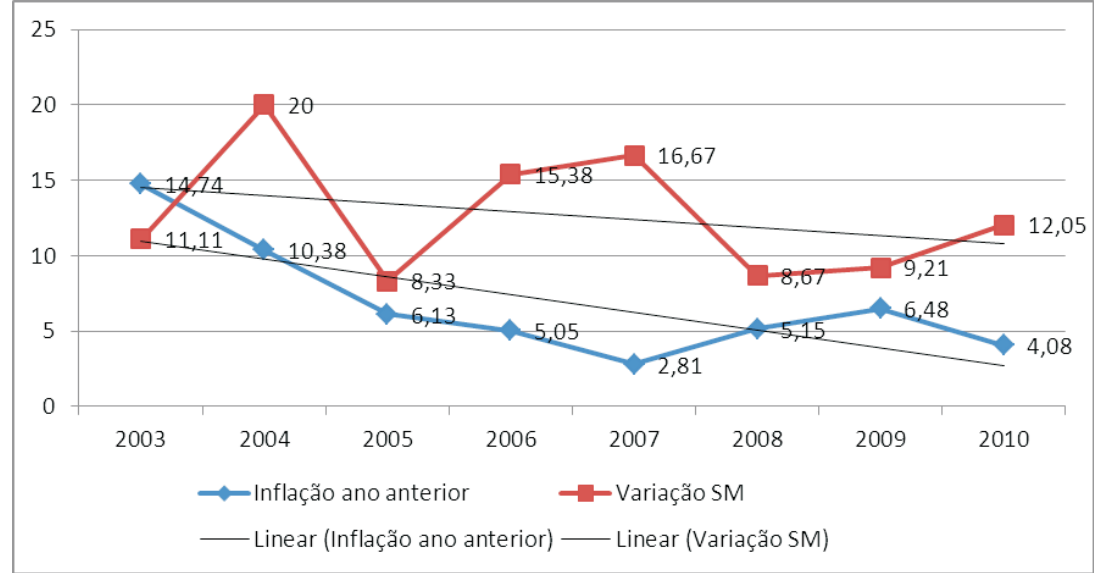

Fonte: IPEADATA e IBGE, vários anos. Elaboração própria.

\section{A RENDA EM MOVIMENTO}

Se o emprego se ampliou, há dois aspectos adicionais que precisam ser considerados. Em primeiro lugar, é inegável que a taxa de inflação sob controle e em patamares decrescentes, entre 2003 e 2007, foi um fator relevante. Porém, mais relevante ainda foi a política de aumento real acima da inflação, de forma sustentável, e depois, inserida em lei - do salário mínimo (SM). Apenas em 2003 a inflação superou o SM, pois este acumulou alta significativa no decorrer do tempo. Em 2004 o SM atingiu a marca de quase 10 pontos; entre 2005 e 2007 atingiu saltos maiores (de 10 pontos e quase 14 pontos, respectivamente), para voltar a se acelerar somente no início de 2010. É sabido que a maior parte do SM é percebida por aposentados e trabalhadores de segmentos básicos da economia, mas o valor referencial baliza tanto os mínimos estaduais (que podem diferenciar-se para cima do piso nacional) como serve de valor de referência para benefícios sociais. Atingindo parcelas em situação mais vulnerável, seu impacto na redução da desigualdade é ainda mais efetivo que políticas focalizadas, como o Programa Bolsa Família, mesmo sendo este um importante fator de estabilidade na renda das famílias - notadamente das camadas mais pobres, como aludido.

Para além do salário mínimo, é certo que, considerando o período entre 2002 e 2009, os salários no setor público representaram importante diferencial ao longo do tempo. A média de R \$1.960,00 em 2002 saltou

DADOS - Revista de Ciências Sociais, Rio de Janeiro, vol. 58, nº 1, 2015 


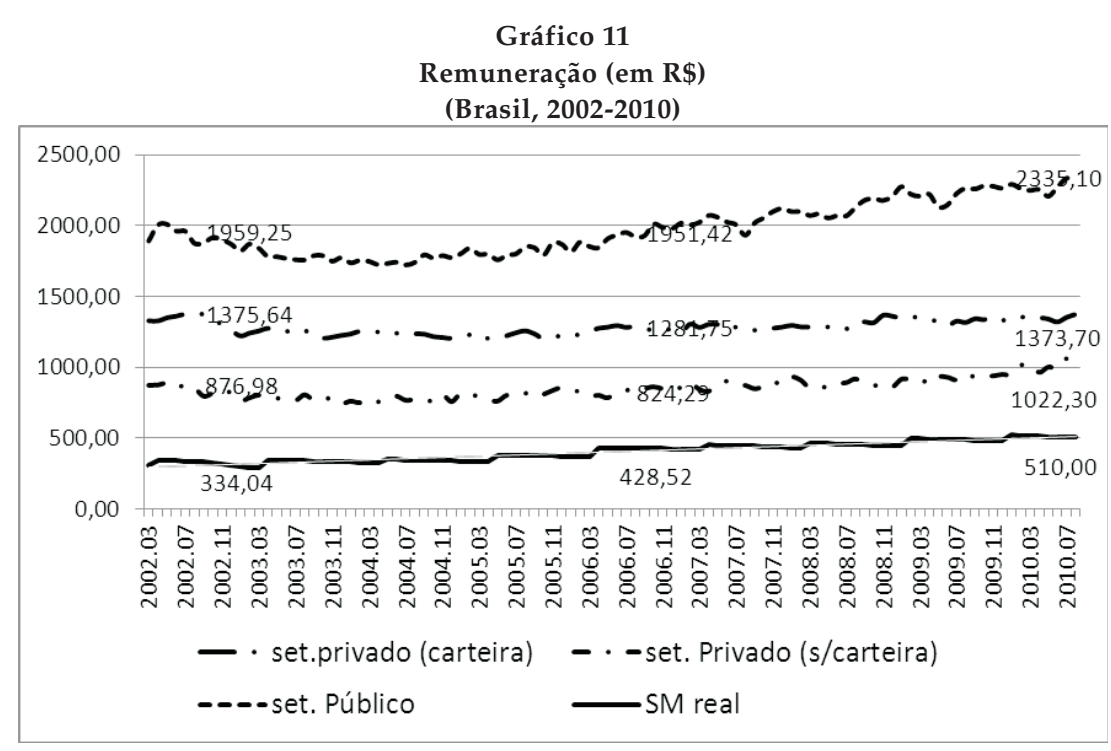

Fonte: IPEADATA/IBGE (vários anos).

para mais de $\mathrm{R} \$ 2.300,00$ em 2010. Esse fator revela dois aspectos da ação governamental que precisam ser considerados, a saber: o maior nível de investimento no reposicionamento do papel do Estado (seu caráter planejador e de prestação de serviços) e a maior atratividade de quadros para o nível público. É visível que o volume dos gastos com pessoal tenha crescido no tempo, mas esse aumento expressa tanto o pessoal empregado quanto o aumento exponencial de contratação de servidores para recomposição dos quadros por meio de concursos públicos.

Segundo o Ministério da Fazenda, entre 2004 e 2008 a despesa com pessoal da União referente aos três poderes permanece relativamente estável em relação ao PIB, como se pode ver na Tabela 1.

Tabela 1

Despesa com Pessoal da União, Todos os Poderes, em Relação ao PIB (Brasil, 2004-2009)

\begin{tabular}{l|c|c}
\hline Ano & \% PIB - Despesa & Crescimento PIB \\
\hline 2004 & 6,03 & 5,71 \\
2005 & 5,8 & 3,16 \\
2006 & 6,32 & 3,96 \\
2007 & 5,89 & 6,09 \\
2008 & 5,54 & 5,19 \\
2009 & 5,8 & $-0,19$ \\
\hline
\end{tabular}

Fonte: Banco Central do Brasil - Dados consolidados (2010). 
Entretanto, como o crescimento do PIB foi importante nos últimos anos, de 1995 a 2002 com média de 2,3\% a.a, e de 2003 a 2012 de 3,6\% a. $\mathrm{a}^{10}$, em termos reais os gastos gerais com pessoal apresentaram aumento nominal e real não desprezível. Isso nada mais significa senão o maior grau de investimento do Estado, a fim de tornar seu aparelho mais robusto, na contramão dos que adotaram plataformas liberais. Note-se que não se tratou de explosão de pessoal nas contas públicas, como quiseram fazer crer a grande mídia e os setores conservadores e neoliberais, e sim, reitere-se, de reaparelhamento do Estado tendo em vista tanto as defasagens em diversos setores como, principalmente, um novo papel estratégico a ele conferido. Outro dado importante é o aumento real do ganho em relação ao setor privado não formal.

Ainda que a economia, como visto, apresente maior grau de formalização, o aumento do salário médio no setor privado formal acelerou mais lentamente que no setor público e no informal: em verdade, caiu e voltou a se recuperar. O ganho efetivo dos trabalhadores informais é mais direto - foi subindo lentamente e se aproximando mais do setor formalizado. Esse é um aspecto interessante nos últimos anos: aumentou o nível de formalização, mais empresas se organizaram e se formalizaram, mas o avanço da economia também ocorreu no setor informal naquilo que se refere à remuneração. Apesar da aparente "contradição", o fato é que ganhos surgiram em ambos os setores. Nesse sentido, é importante apontar que possivelmente o setor informal, no capitalismo contemporâneo, esteja inserido estruturalmente na dinâmica de cadeias produtivas, referendando - em tese, dada a necessidade de pesquisas de longo prazo que a comprovem - a perspectiva do desemprego estrutural tecnológico, que se apoiaria sistemicamente num amplo setor informal.

O salário mínimo apresentou importante variação, como já observado. É o que demonstra o Gráfico 12. O ganho real do salário mínimo vem se ampliando ano a ano, como é sabido, mas o avanço real, descontada a inflação, oferece dimensão mais clara desse processo. A cada ano o SM sofre aumento, mas também enfrenta a desvalorização monetária; por isso a forma de "degraus" no gráfico. Mas, sob qualquer leitura, $o$ aumento real é nítido, até porque previsto em legislação, o que é uma importante inovação do governo Lula da Silva, tornado lei (o aludido aumento real acima da inflação), no governo Dilma Rousseff. Um efeito direto desses rendimentos, combinado com maior oferta de emprego em uma economia mais "acelerada", tem impactos positivos sobre a 
Gráfico 12

Salário Mínimo Real (em R\$)

(Brasil, 2002-2010)

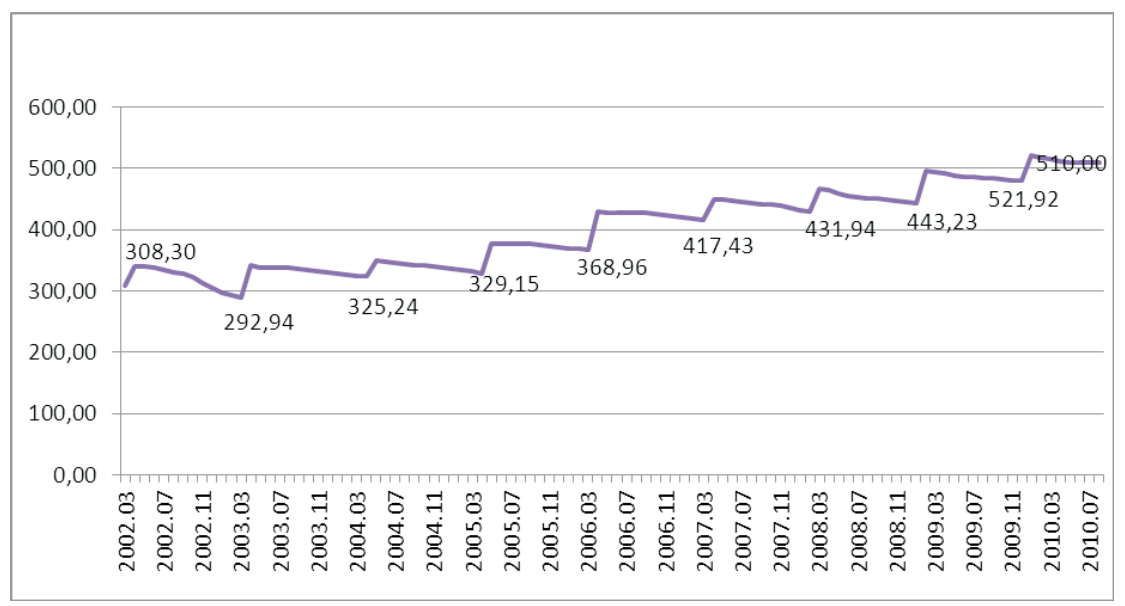

Fonte: IPEADATA (vários anos). Elaboração própria.

renda geral, as contas previdenciárias e o mercado interno: este último, um importante estabilizador da economia. Mais ainda, pode-se dizer que um mercado interno amplo, estruturado e sustentável ao longo do tempo é uma demanda histórica da sociedade brasileira e fator decisivo da estabilidade do tecido social.

\section{POBREZA E DESIGUALDADE}

Se existe uma situação em que a combinação virtuosa de crescimento econômico, emprego e renda apresenta reflexos (ainda que incapaz, nesse curto prazo, de retirar do país a condição dos mais desiguais do mundo), esta se dá nos indicadores de pobreza e desigualdade. É sabido, pela literatura, que o conceito de pobreza é multidimensional e pode considerar aspectos como "privação de capacidades" (Sen, 2000) ou, ainda, medidas quantitativas referidas aos níveis de mínimo ou suficiente para a vida, estabelecidos em termos de alimentação, vestuário e bens básicos. Ou, no caso da extrema pobreza ${ }^{12}$, ou indigência, o mínimo levaria em conta possibilidades nutricionais abaixo de um standard. Sem pretender tomar um lado na polêmica, sob a ótica quantitativa do IBGE as taxas de pobreza e de extrema pobreza, no âmbito da privação de necessidades básicas, vêm caindo de forma segura e claramente mais acelerada desde 2003. É o que se vê no Gráfico 13. 
Gráfico 13

Taxa de Pobreza e Extrema Pobreza

(Brasil, 1995-2009)

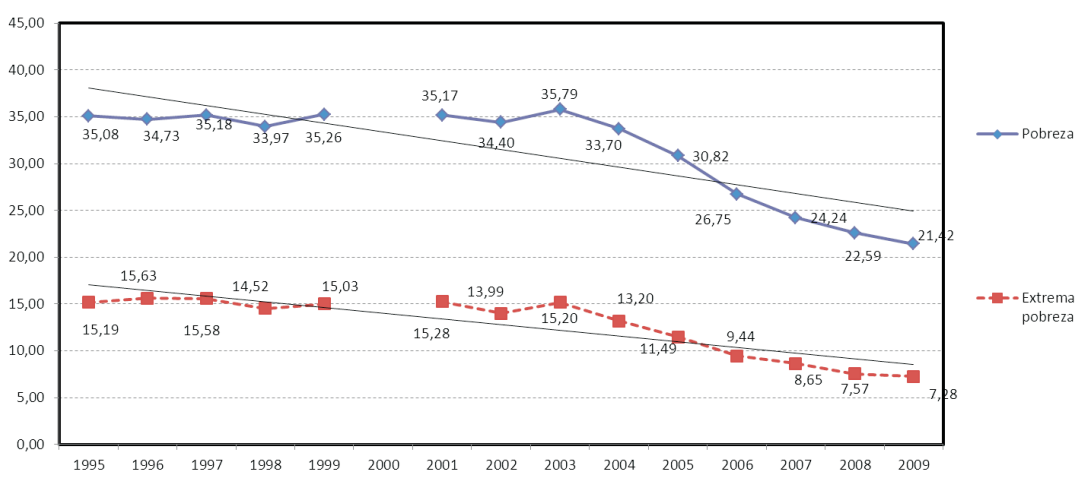

Fonte: IPEADATA/IBGE, vários anos. Elaboração própria.

Note-se que a queda de $35,08 \%$ para $21,4 \%$ na taxa de pobreza é um grande movimento, mas a de $15 \%$ para $7,3 \%$ na extrema pobreza é ainda mais significativa. Independente das controvérsias que cercam o debate (sobre os significados e os parâmetros de pobreza e as formas de combatê-la, pois fogem aos objetivos deste artigo), é essencial observar que, sob critérios quantitativos mensuráveis, o recuo é nítido. De acordo com os indicadores adotados, o impacto dessas mudanças atua diretamente sobre a fome e a carência alimentar, uma vez que a medida quantitativa é "nutricional".

Aqui, programas como o $\mathrm{PBF}^{13}$ têm papel acessório importante, atuando mais diretamente sobre a pobreza. Pela lei que o criou ( $\mathrm{n}$ o 10.836 /04), o PBF paga benefícios fixos às famílias pobres ou extremamente pobres ( $\mathrm{R} \$ 68,00$ hoje) e auxílios variáveis às famílias com crianças e adolescentes na mesma condição (de $\mathrm{R} \$ 22,00$ e $\mathrm{R} \$ 33,00$, respectivamente). O mesmo ocorre com o Benefício de Prestação Continuada $(\mathrm{BPC})^{14}$ : dados do Ministério do Desenvolvimento Social indicam um número crescente e importante de famílias beneficiadas, conforme o Quadro 2.

Segundo estudo de Queiroz et al. (2010), com base no MDS, em 2009 o total despendido com o BPF atingiu R $\$ 11,3$ bilhões, enquanto o BPC representou $\mathrm{R} \$ 15,39$ bilhões; em 2004 eram respectivamente $\mathrm{R} \$ 3,8$ e

DADOS - Revista de Ciências Sociais, Rio de Janeiro, vol. 58, n- 1, 2015 
Quadro 2

Famílias Beneficiárias do PBF e

Pessoas Beneficiárias do BPC

(Brasil, 2006-2010)

\begin{tabular}{|l|c|c|}
\hline Ano & $\begin{array}{c}\text { Famílias Beneficiárias } \\
\text { (em milhões) }\end{array}$ & $\begin{array}{c}\text { Pessoas Beneficiárias } \\
\text { (em milhões) }\end{array}$ \\
\hline 2006 & 10,9 & 2,5 \\
\hline 2007 & 11,02 & 2,7 \\
\hline 2008 & 10,5 & 2,9 \\
\hline 2009 & 12,4 & 3,1 \\
\hline 2010 & $12,6^{*}$ & $3,3^{* *}$ \\
\hline
\end{tabular}

Fonte: Ministério do Desenvolvimento Social (MDS)/IPEADATA, vários anos. Elaboração própria.

* Até outubro de 2010; ** até setembro de 2010.

$\mathrm{R} \$ 5,8$ bilhões e, em 2008, $\mathrm{R} \$ 10,6$ e $\mathrm{R} \$ 13,8$ bilhões. O nordeste representou, em 2009, 52,3\% dos beneficiários do PBF e 35,6\% daqueles que percebem o BPC (ibidem:15-16). Como detalhe adicional, o número percentual de beneficiários do PBF no nordeste caiu: eram 57\% em 2004 e $52,4 \%$ em 2006. Se considerarmos o total de pessoas atingidas, em 2010 o PBF estaria se aproximando da marca de 50 milhões de pessoas nas famílias atendidas, ou mais de $25 \%$ da população brasileira. Em 2013, o gasto foi de 24,9 bilhões de reais ${ }^{15}$.

Em termos da despesa, o BPC representou apenas 0,4\% do PIB em 2009, enquanto o Bolsa Família despende $0,3 \%$ do PIB. Sob qualquer ângulo, por seus resultados esses programas não representam nem de forma longínqua qualquer ameaça fiscal às contas públicas e apresentam, segundo o melhor conceito do mainstream econômico, "alto custo efetivo", isto é, representam, ao contrário, dispêndios muito modestos, seja se comparados ao pagamento de juros da dívida interna, seja quando os comparamos com gastos em países similares ${ }^{16}$. Ao conjugar-se política de valorização do salário mínimo e ampliação do crédito, transferências de renda focalizadas, programas universais, controle da inflação e queda (ainda que lenta) dos juros, percebe-se o modus operandi da política pública brasileira. Esse arranjo não suprime, contudo, contradições de inúmeras ordens, tais como o ainda altíssimo patamar da taxa básica de juros, aumentado toda vez que a inflação ameaçou subir, mesmo que minimamente, nos governos Lula da Silva; o peso do serviço da dívida pública interna; a estrutura tributária perversa; a assimetria orçamentária e do financiamento público em relação aos grandes 
empreendimentos em detrimento dos micro, pequenos e médios empreendedores; entre inúmeros outros problemas estruturais não enfrentados. Mas tais contradições não impediram a existência de avanços, reitere-se. Afinal, com a redução da pobreza, resultado desse conjunto de estratégias conjugadas, a desigualdade também apresentou queda relevante. No Gráfico 14 observamos a evolução do índice de Gini desde 1995:

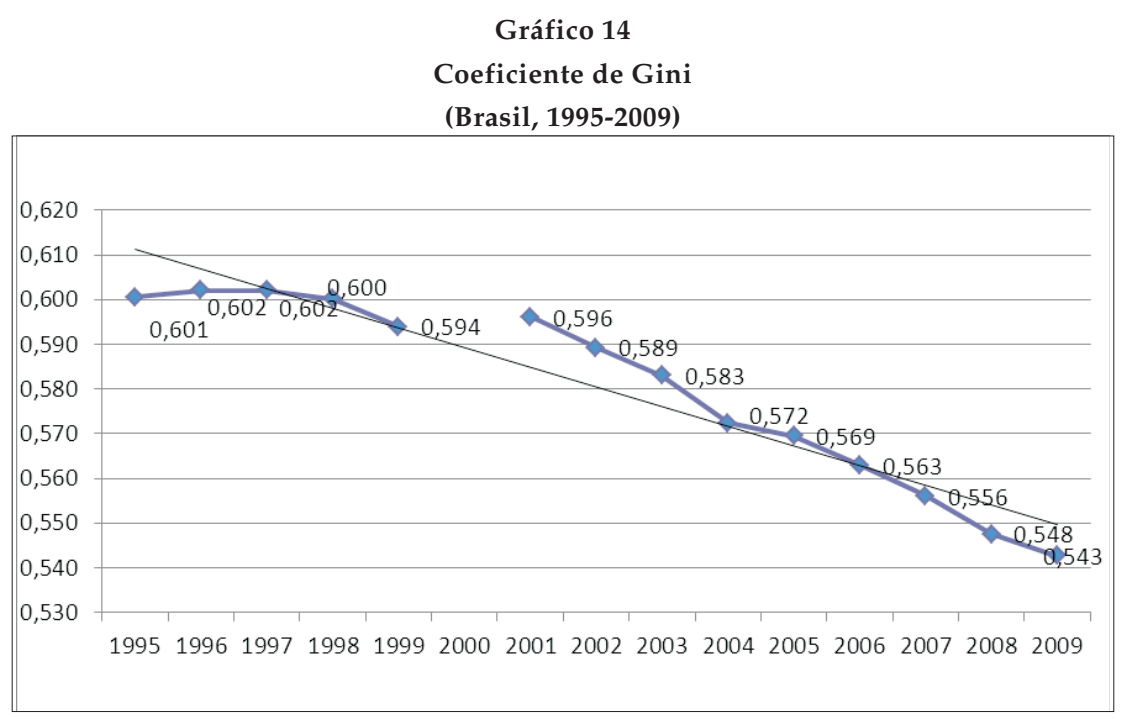

Fonte: IPEADATA, vários anos. Elaboração própria.

Malgrado a clara linha de tendência (a descontinuidade deve-se a uma mudança de metodologia em 2000), a antiga "estabilidade inaceitável", expressa por Barros et al. em 2001, foi substituída pela queda significativa da concentração de renda desde 2002. Entre 2001 e 2009 o recuo foi de 0,596 para 0,543, tendo se acelerado a partir de 2003. Esse dado se repete para o Coeficiente $T$ de Theil, e talvez seja um dos mais fortes indicadores do movimento da sociedade, com reflexos no consumo, no crédito, no investimento e, certamente, no mercado interno: daí o frenesi acerca da chamada "nova classe $C$ ". Considerando-se a distribuição regional de uma política pública como o PBF, este pode contribuir também, ao longo do tempo, para a redução das desigualdades regionais, dada sua atuação no nordeste. Ressalte-se que a existência do Cadastro Único gerido pelas prefeituras é um instrumento poderoso de acompanhamento das ações. Ainda que possam existir problemas gerenciais no cadastro, a ação do MDS tem sido crescente, com vis-

DADOS - Revista de Ciências Sociais, Rio de Janeiro, vol. 58, nº 1, 2015 
tas a preservar a integridade e a respeitabilidade do programa, uma vez que frequentemente atacado pelos setores conservadores. Em contraposição, deve-se ressaltar o reconhecimento mundial do programa, considerado pela ONU como "paradigmático", a ponto de ser recomendado internacionalmente. Comparado com o brasileiro, o Programa Oportunidades do México é o que mais se aproxima dos padrões de modelos de programas de transferência de renda, que passaram a ser referenciados pelo Banco Mundial, antes resistente a soluções que não o "mercado".

Aspecto relevante quanto aos temas da desigualdade e pobreza, combinado com índices de pleno emprego atuais (inferiores a 4,9\%), é a distribuição funcional da renda nacional. Por este elemento macroeconômico é possível perceber também uma paulatina mudança, cuja tendência é positiva, conforme demonstra o Comunicado 47 , do Ipea.

\section{Gráfico 15 \\ Brasil}

Evolução da Participação do Rendimento do Trabalho na Renda Nacional e do Grau de Desigualdade em Anos Selecionados (em \%)

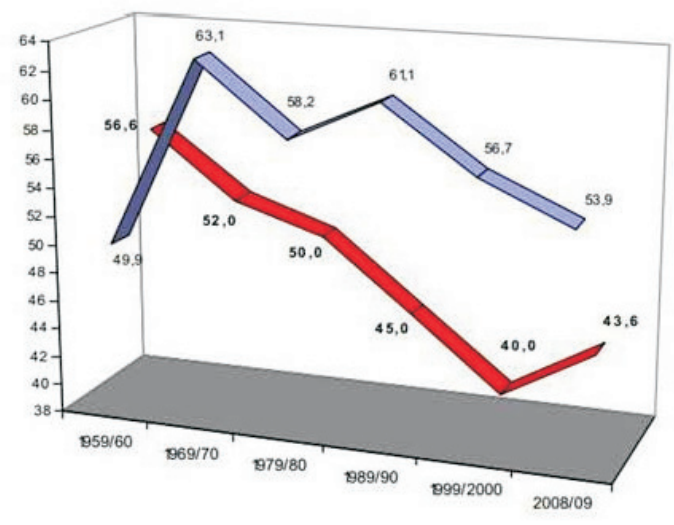

aindice Gini de desigualdade de renda do trabaltho a Participaçąo do rendimento do trabaltho na renda nacional

Fonte: IBGE - Contas Nacionais. Elaboração própria. Disponível em: http:/ / www.ipea.gov.br/portal/images/stories/PDFs/100505_comunicaipea_47_apresentacao.pdf. Acesso em 20/5/2013.

Como se observa, há uma crescente participação do trabalho na renda nacional, que é, por si só, um indicador extremamente positivo, mesmo que, comparativamente a outros países similares, ainda seja menor que o desejável. 
O Brasil tem ainda composição demográfica que, no tempo, pode ajudar a minimizar alguns problemas e indicar resultados. $\mathrm{Na}$ "ponta" inferior do ciclo, a fecundidade vem enfrentando forte redução, como se observa Gráfico 16:

\section{Gráfico 16}

Taxa de Fecundidade (\%)

(Brasil, 1980-2009)

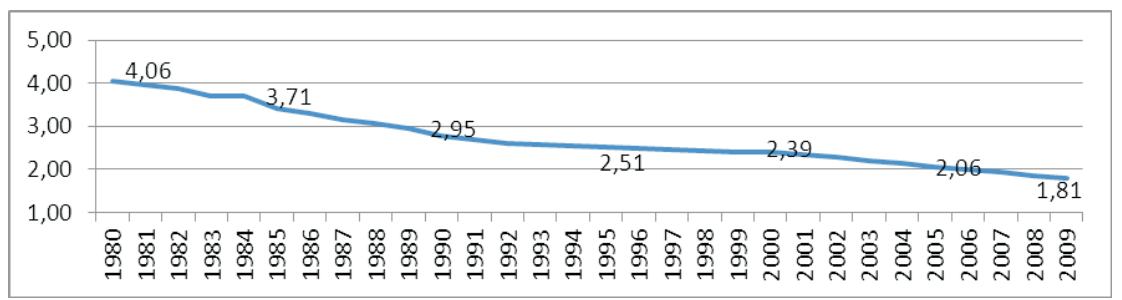

Fonte: IBGE, vários anos. Elaboração própria.

Se a redução de 4,06 filhos em 1980 para 2,95 filhos em 1990 já era expressiva, deu-se novo salto, agora para menos de dois filhos por mulher. A diminuição da pressão demográfica na "parte de baixo" da sociedade trará reflexos importantes para o mercado de trabalho nos próximos 20 anos, reduzindo a pressão sobre o emprego. Mantidas as condições de crescimento e estabilidade, ainda que em equilíbrio precário em um ou outro ano - sem contar situações de crise internacional não previstas -, a combinação de políticas de formação profissional, treinamento de mão de obra com estabilidade e crescimento poderão reduzir ainda mais o desemprego e (continuar a) subsidiar a Previdência, ainda que pressões advindas do fator etário também afetem, em momentos distintos, o caixa.

Deve-se ressaltar, alternativamente, o impacto negativo de um país ascendente economicamente possuir um número grande de pessoas mais velhas, em comparação ao número de jovens em idade ativa. Para alguns, isso poderia levar à necessidade de importação de mão de obra, como, aliás, vem ocorrendo nos setores qualificados da economia. São diversos os cenários potenciais quanto a mutações etárias, ao lado de outras, que impactam a sociedade brasileira, mas que neste artigo são tratados apenas como uma das variáveis importantes da macrodinâmica social brasileira, não sendo, portanto, objeto aprofundado de análise. Como dissemos, importa-nos o caleidoscópio dos fa- 
tores componentes da macrodinâmica, e não o inventário analítico de variável por variável.

O Gráfico 17 indica a longevidade e o grande salto representado pela expectativa de vida ao nascer. Em quase 30 anos, a expectativa saltou de 62,6 para 73 anos e permanece subindo. Este envelhecimento tradicionalmente impacta duas áreas-chaves em seguridade: Previdência e Saúde. A Saúde representa um dos principais gastos incrementais com o fator idade, e demanda investimentos contínuos na ponta - máquinas, equipamentos, medicamentos, atendimento hospitalar, entre outros - e a necessidade de universalização da saúde preventiva. A conta "Saúde" é a segunda no orçamento da União, atrás apenas da Previdência, e não se reduzirá, pois, devido ao seu caráter universal, a tendência é crescente.

Gráfico 17

Esperança de Vida ao Nascer

(Brasil, 1980-2009)

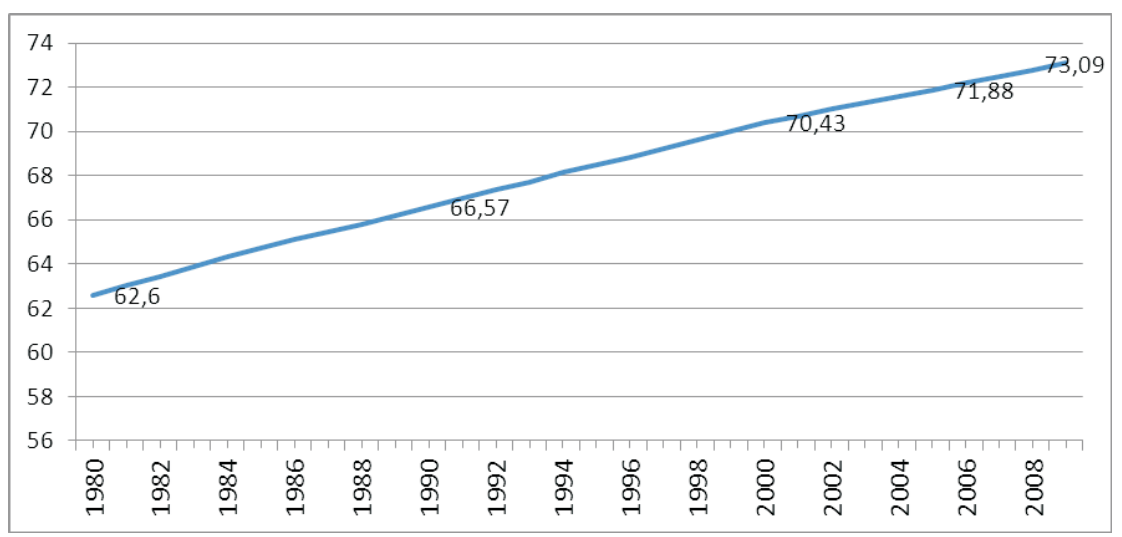

Fonte: IBGE, vários anos. Elaboração própria.

A outra conta, que é a principal despesa da União, é a Previdência (Instituto Nacional do Seguro Social - INSS). Esta é impactada diretamente pelo envelhecimento e absolutamente sensível ao mercado de trabalho formal ${ }^{17}$. Na situação atual, a tendência de alta do número de aposentados dá-se pela evolução natural e vegetativa, ainda que o aumento entre 1995 e 2009 tenha atingido dois pontos. Mas, como o aumento dos contribuintes, estimulado pelo nível crescente de formalização, cresceu no mesmo período de $22,8 \%$ para $28,54 \%$, há espaço 
Gráfico 18

Aposentados e Contribuintes da Previdência

(Brasil, 1995-2009)

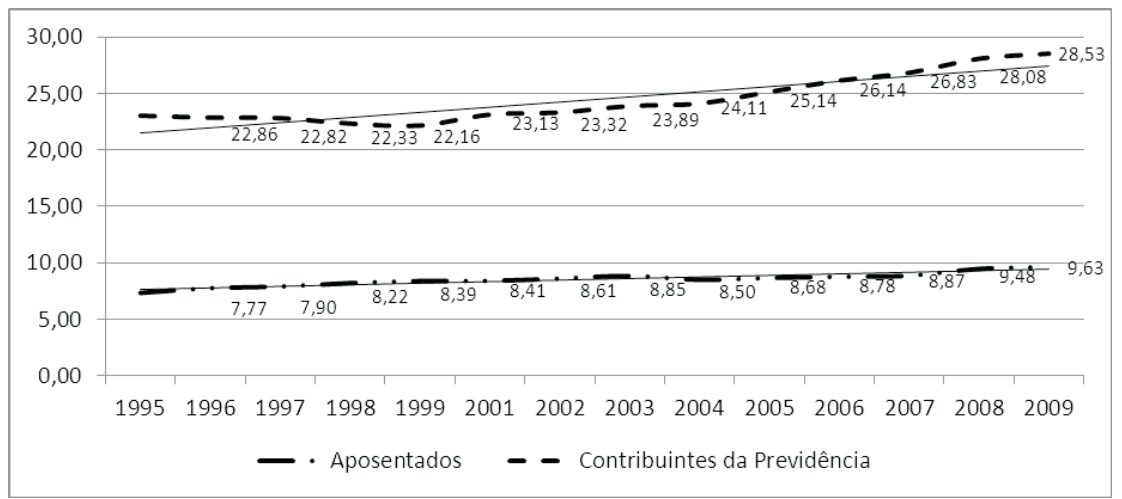

Fonte: IPEADATA, vários anos. Elaboração própria.

para ajustes. Além disso, a população em idade ativa deve ainda crescer por cerca de 20 anos, até 2030, quando então a pressão sobre o caixa tornar-se-á maior. Assim, após esse período, como aludimos, a questão dos percentuais entre população em idade ativa e idosos aposentados pode produzir impactos significativos no caixa do Estado.

Se persistirem instabilidades na Previdência, a necessidade de desoneração na folha e um futuro e impopular aumento ligeiro na idade mínima para se aposentar poderão se tornar imperativos, mas também é verdade que não existe possibilidade de forte desequilíbrio nas suas contas. A imagem de uma "bomba" armada para detonar no médio prazo, como setores conservadores/liberais não se cansam de alardear, faz parte da luta política e ideológica em curso, em que os números são interpretados a bel-prazer.

Nesse sentido, observe-se que a curva de arrecadação está apontada para cima, resultado também da recuperação econômica do país.

Ainda assim, as contas da Previdência, pelo resultado do fluxo de caixa, permanecem no vermelho. Por este valor, a conta previdenciária por meio do INSS apresenta saldo negativo de R $\$ 45$ bi em 2009, ainda que um saldo operacional positivo de $\mathrm{R} \$ 474$ milhões.

Como pode ser observado, o desafio da Previdência brasileira quanto ao INSS tem origem nas opções adotadas no pagamento de benefícios, algumas desde o fim da Assembleia Constituinte em 1987 e 1988. Mas,

DADOS - Revista de Ciências Sociais, Rio de Janeiro, vol. 58, nº 1, 2015 
Gráfico 19

Valor Arrecadado pelo INSS (R\$ Bi)

(Brasil, 1995-2008)

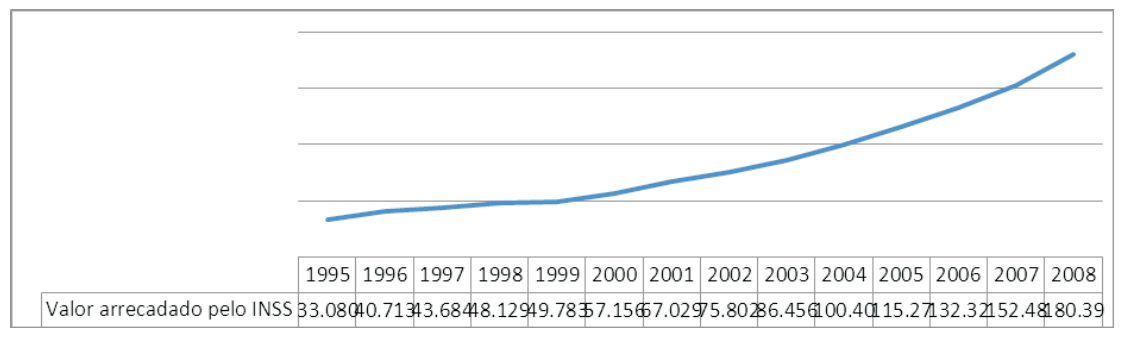

Fonte: IPEADATA, vários anos. Elaboração própria.

Tabela 2

Previdência Social - Fluxo de Caixa (R\$ milhões)

(Brasil, 2004-2009)

\begin{tabular}{l|c|c}
\hline Ano & Saldo Operacional & Saldo Previdenciário \\
\hline 2004 & 10.994 & -43.390 \\
2005 & 1.177 & -48.431 \\
2006 & 1.583 & -53.283 \\
2007 & -6.268 & -54.051 \\
2008 & 1.269 & -39.349 \\
2009 & 474 & -45.620 \\
\hline
\end{tabular}

Fonte: Banco Central do Brasil - Indicadores Econômicos Consolidados, vários anos. Elaboração própria.

para além de qualquer outra consideração, a Previdência apresenta déficit no saldo previdenciário e um superávit no saldo operaciona $\mathrm{l}^{18}$. O primeiro é calculado considerando as contribuições de empregados, empregadores e autônomos ao INSS, retirando daí os benefícios pagos. Para efeito da arrecadação exclusivamente previdenciária, são consideradas somente as contribuições de autônomos, empregados e de empregadores sobre a folha de salários. Pela Constituição de 1988, Previdência Social, Saúde e Assistência Social formam um único sistema, o da Seguridade Social. Seu financiamento, além das contribuições citadas sobre a folha, considera tributos sobre o faturamento e o lucro, como os recursos da Contribuição para o Financiamento da Seguridade Social (Cofins), sobre faturamento; da Contribuição Social sobre o Lucro Líquido (CSLL), de parte da receita dos concursos de prognósti$\cos$ (loterias); e de taxas sobre a importação de bens e serviços. A totali- 
dade da seguridade, vista como um todo, tornaria esse orçamento específico superavitário. Não é esse o entendimento das autoridades econômicas e da regulamentação do Orçamento Geral da União, isolando a conta Previdência das demais da seguridade. Assim, a Previdência, embora vista como um problema pelos conservadores e liberais, é fundamental aos trabalhadores e ao país enquanto "comunida$\mathrm{de}^{\prime \prime}$ que compartilha valores e a riqueza produzida. Trata-se da mais importante ação social operando em âmbito federal e, além disso, com "responsabilidade fiscal"19. Neste caso, a Previdência, e suas relações com o salário mínimo, é também um instrumento essencial na redução da pobreza.

\section{À GUISA DE CONCLUSÃO: MOVIMENTO PARA MUDANÇA?}

A massa de dados ou o conjunto de "evidências" citadas não tem a finalidade de impor o "positivismo da empiria". Procurou-se estabelecer um grande painel da macrodinâmica social recente do Brasil por meio do mapeamento socioeconômico, ao lado de variáveis macroeconômicas e do cenário internacional; nesse sentido, enfatize-se a percepção de movimento. As oscilações recentes quase falam por si. O objetivo central foi estabelecer certa "radiografia" das mudanças, entremeadas por contradições e permanências, aliada, reitere-se, à noção de movimento da macrodinâmica recente do Brasil.

É plausível dizer que ações governamentais mais efetivas e com grau de impacto considerável recuperaram o debate sobre a participação estatal na sociedade e no mercado, sobretudo naquilo que se refere a políticas sociais com impactos no mercado interno e na diminuição da desigualdade.

Voltando à questão do movimento, a trajetória brasileira apresenta vários momentos de ruptura, mesmo que permeada de continuidade. Vejamos alguns exemplos:

O significativo deslocamento social operado a partir de 1930, a modernização autoritária promovida entre 1937 e 1945 e depois, pelos militares; a industrialização e a ordem burguesa como partes de uma nação modelada e remodelada pelo alto, com rasgos de intervenção popular; a redemocratização a partir de 1985 e a Constituinte de 1987/1988 (sinal inequívoco de que as políticas sociais e a seguridade como um todo precisavam ser incorporadas à "civilização brasileira") permitem conceber uma trajetória peculiar, em que o presente não se faz refém, 
porém também não se dá independente deste legado. Em paralelo à redemocratização, a sucessão de crises econômicas dos anos 1980 fez crer na dependência da "ação pelo alto", a despeito de que essa "modernização" agora ocorria numa ordem burguesa democrática e contrária à herança histórica dos regimes autoritários de um passado "profundo" 20.

Fernando Collor de Mello nada mais foi do que a expressão desse mundo contraditório. Já o governo Cardoso entendeu perfeitamente a "nova" modernização, agora nos quadros da chamada "globalização" da era Clinton: os exuberantes anos 1990, segundo Stiglitz (2003). A inserção do Brasil nesse cenário guarda caráter de complementaridade e "vantagem comparativa", e um porto de estabilidade da grande mobilidade do capital. Lula da Silva, de certa forma, representa a mesma vontade de mudança de nosso passado, mas sob outro signo.

Navegar pela história é arriscado, ainda mais no curto espaço de um artigo e, mais ainda, no intervalo de pouco mais de uma década. A estabilização econômica do período Cardoso - tendo como contexto as reformas introduzidas por Collor de Mello-, com seu ambiente de confiabilidade ao investimento, restrição monetária e fiscal, redução da capacidade estatal e privatização trouxe elevado custo ao país em seus resultados macrossociais e econômicos. Já Lula da Silva, surgido do mesmo universo modernizador antitradicional, em nome da governabilidade e da estabilidade manteve o mesmo cenário nos primeiros três anos e, de certa forma, nunca se livrou dele. Mas agiu em outro sentido da modernização e do reforço do Estado pela ampliação de suas capacidades, no sentido que Peter Evans nomeia como "autonomia inserida": mais dirigido à inserção social, com maior capacidade regulatória e legitimação de suas ações (1995).

Como dissemos, o período que se segue a partir de 2005 representa retomada da agenda social e do crescimento econômico em bases combinadas entre o fortalecimento do mercado interno, a ampliação do crédito, o aumento e o estímulo à taxa de investimento, a maior representatividade no comércio mundial (com a aludida ressalva do declínio dos produtos industrializados) e diversificação de parceiros e um Estado ativo no cenário internacional. Em outras palavras, a agenda de uma nova modernização mudou de patamar: tratou-se da recusa do passado por um projeto de integração à civilização burguesa nos marcos do que se entendeu ser "possível". Essa integração representa um 
salto qualitativo de grande relevância no combate à iniquidade, mesmo que com a ressalva de que "poderia ser mais ousada". Nesse sentido, basta observar, de forma combinada, como procuramos demonstrar nas seções precedentes as ações em torno das políticas sociais de transferência e criação de renda, da valorização do salário mínimo, da estabilização, da taxa de emprego, do fortalecimento do mercado interno e do crescimento (a despeito da polêmica acerca do papel jogado pela economia internacional, notadamente quanto à participação das commodities), entre outras.

Permanecemos nos marcos revoltos e polissêmicos da "modernização", mas com outro rosto e outra forma. Mais uma vez, a diferença maior é dada pela ação política.

Entretanto, quando o debate desloca-se para a sociologia, há perguntas inevitáveis. Modernização para onde? Quais mecanismos estão operando silenciosamente, no tempo, e em que direção? Em suma, qual a natureza da mudança? E, mais ainda, existe mudança? Uma resposta definitiva ainda não pode ser dada, sobretudo a partir das grandes e contínuas manifestações de rua que eclodiram a partir de junho de 2013. Contudo, nos marcos dos indicadores e dados estatísticos, há alterações que não podem passar despercebidas. Nesse sentido, não é possível imaginar tamanha mobilidade de pessoas e de recursos, acelerada no pós-2002, sem efeitos significativos sobre a ordem política, social e simbólica: uma vez mais, as manifestações de junho de 2013 expressaram um novo patamar de problemas, tendo em vista inserções e incorporações no sistema social, em sentido lato. Assim, muda-se em direção a um futuro ainda indefinido. Os setores médios, ampliando seu espaço econômico e político, tendem a produzir efeitos até agora desconhecidos. Aparentemente dá-se a progressiva "conservadorização" das "novas" classes médias, capazes de contestar o avanço das políticas de corte estatal que paradoxalmente as beneficiaram. Será possível reduzir de forma continuada a pobreza promovendo crescentes avanços na redução da desigualdade? Cabe recordar ainda que efeitos de desigualdade operam por uma gramática também diferenciada da renda, como, por exemplo, pelo gênero ou etnia.

O conhecimento sobre as mudanças recentes ainda não foi amadurecido pelo tempo, nem pode superar a aguda observação feita por Wanderley Guilherme dos Santos sobre a população pobre brasileira: para ele, sem disponibilidade para os custos da ação coletiva e para

DADOS - Revista de Ciências Sociais, Rio de Janeiro, vol. 58, nº 1, 2015 
absorver fracassos, mal informada e com baixa noção de direitos, arremessando para baixo a confiança institucional, ainda que isso não possa ser confundido com tendência ao imobilismo ou alienação, há uma situação estruturalmente grave. Em suas palavras, "há evidente descompasso entre a magnitude das carências sociais e o empenho da sociedade em resolvê-las. Não sobra tempo para isso, visto a alocacão prioritária de tempo e recursos dos indivíduos na solução de urgentes problemas pessoais e familiares" (Santos, 2006:176). Se isso for verdade, pode ser que o movimento recente no Brasil tenha sido de maior reconhecimento dos direitos, mas ainda num cenário de acumulação pouco contestada e sem redistribuição intensiva no longo prazo, dado que nos marcos de um sistema internacional de produção "flexível" e pró-capital (embora a criação de emprego no Brasil conteste parcialmente os pressupostos desse modelo, como vimos). Isso ainda está em curso, e alguns anos são claramente insuficientes para superar os problemas especificamente sociais e econômicos daí decorrentes, ainda mais, como aludimos, tendo o legado de séculos de iniquidade. Há, contudo, mudanças a caminho capazes de rever e reverter o histórico legado de desigualdade e exclusão, além da permanente contradição entre modelo de acumulação e ação política nacional.

O governo Lula da Silva introduziu a agenda da mudança pela via da ação estatal e da redução do déficit social - com um sem-número de contradições e assimetrias -, alavancado também por uma visão de desenvolvimento e de políticas setoriais, inserindo o país, política e comercialmente, de forma mais incisiva no cenário internacional.

Embora seja necessária a análise de séries longas para conclusões mais peremptórias, os dados expressam a construção de um vetor mais inclusivo e igualitário. Não se sabe ainda, portanto, o sentido mais definitivo do movimento e da intensidade e estabilidade da mudança, apesar de haver um vetor. Afinal, uma vez colocadas em ação, as forças da sociedade produzem efeitos conjugados que podem produzir novo perfil para a política e sociedade brasileiras - daí sua macrodinâmica. Mas, para desdobrar esses argumentos, são necessárias mais pesquisas, sobretudo no que tange, também como aludimos, à interpretação entre mercado formal e informal (suas possibilidades e limites mediante a lógica do capitalismo contemporâneo). Daí os desafios que se colocam ao Estado e à sociedade.

Por fim, o próprio sentido de mobilidade social no Brasil no período recente, notadamente nos governos Cardoso (por meio da estabilização 
da moeda) e Lula da Silva (pela via da inclusão social), parece indicar a coexistência de elementos novos e antigos, numa dialética ainda pouco compreendida. Seja como for, a inclusão social, mesmo que lenta e, de certa forma, marginal - tendo em vista os hercúleos desafios sociais do país -, é por si só novidade em razão de seu intuito universalista; é, além do mais, mudança de rota que necessita de entendimento aprofundado sobre suas características, lógica, dinâmica e destino.

Este artigo procurou por meio do cruzamento de inúmeros dados e da tentiva de interpretá-los segundo uma lógica, um vetor, simultaneamente ao diálogo com a literatura, demonstrar o sentido da macrodinâmica social brasileira na última década e meia: suas mudanças, continuidades, contradições e desafios.

Para tanto, mobilizou diversas variáveis, tais como a ampliação de vagas de trabalho formal e ocupação informal; a renda, tanto do trabalho como a referente às transferências governamentais distintas, como bolsas e o próprio crédito; o papel da valorização do salário mínimo e da Previdêncial Social, uma vez que um dos pilares do tecido social; elementos macroeconômicos impactantes na vida social, caso do crescimento do PIB, entre outros; e o papel do cenário internacional, dado que decisões políticas nacionais não estão desconectadas dos padrões de acumulação internacionais e da teia de relações dos fluxos mercantis e financeiros e dos Estados nacionais.

Esperamos que outras pesquisas deem sequência à análise e compreensão de nossa macrodinâmica social, seja pela via do aprofundamento das variáveis aqui trazidas, seja pela observação de outras, assim como coloque à prova a questão do possível "movimento" da sociedade brasileira como um vetor voltado à universalização de direitos e, consequentemente, ao combate à desigualdade por meio de processos de inclusão (estatais e mercantis). Este artigo pretendeu contribuir para chamar a atenção para problemas ao mesmo tempo históricos e contemporâneos de nossa sociedade.

(Recebido para publicação em novembro de 2012)

(Reapresentado em junho de 2014)

(Aprovado para publicação em novembro de 2014)

DADOS - Revista de Ciências Sociais, Rio de Janeiro, vol. 58, nº 1, 2015 


\section{NOTAS}

1. Este texto não objetiva analisar o debate acerca do padrão de inserção internacional do Brasil nos governos Lula da Silva e Dilma. Apenas constata-se que houve diversificação de parceiros internacionais em diversas dimensões, com o objetivo de diminuir a dependência política e econômica com os gigantes do sul (EUAe Europa). Tais dimensões voltam-se às arenas econômica/comercial, política/estratégica, geopolítica/geoeconômica.

2. Reafirme-se o inédito papel protagonista do G-20 neste início de século XXI e, particularmente, após o crash de 2008: grupo de países ora denominado "em desenvolvimento", ora "emergente", e que refazem o sentido de "centro e periferia".

3. A relevância dos gastos sociais na economia do país e do incremento da atividade econômica do mercado interno podem ser percebidas pelos resultados de queda: na desigualdade como um todo (medida pelo índice de Gini), nas diferenças da renda do trabalho e nas taxas de pobreza absoluta e extrema. Tanto que, em 2016, o Brasil pôde romper com uma das marcas mais agudas do "subdesenvolvimento": a superação da pobreza extrema. A explicação para tanto advém de que o rendimento atual das famílias depende, em média, de quase um quinto das transferências monetárias derivadas das políticas previdenciárias e assistenciais da seguridade social brasileira. Deve-se notar que, antes da Constituição Federal de 1988, as famílias não chegavam a deter, em média, 10\% dos seus rendimentos das transferências monetárias (Pochmann, 2011).

4. É claro que a China representa outra perspectiva, no sentido de emprego massivo, de certa forma "fordista", em razão de um conjunto de características inexistente em praticamente todos os países.

5. Ver, entre outros, o trabalho de Baltar et al. (2010).

6. Disponível em http://www.portal.mte.gov.br/data/files/.../Informalidade2.pdf. Acesso em 15/5/2013.

7. Do ponto de vista político, a queda do ministro José Dirceu - para além de seu contraponto econômico com Palocci - também representou espécie de recomeço do governo Lula da Silva, pois permitiu confluência às ações governamentais, dispersas com a sombra política exercida pelo então ministro, notadamente num regime de coalizão.

8. Note-se que, como aludimos, o cenário internacional restritivo é uma variável extremamente importante à análise da macrodinâmica interna de países como o Brasil; contudo, como queremos demonstrar, não se trata de "camisa de força" capaz de embotar toda e qualquer saída ao desenvolvimento. A ampliação do emprego é a demonstração cabal de que, num prazo de observação um pouco mais longo, é possível compreender como políticas "desenvolvimentistas" - que impliquem indução do Estado ao crescimento com distribuição, portanto opostas à cartilha neoliberal, notadamente advinda do chamado Consenso de Washington - podem ser utilizadas por meio de fatores macroeconômicos voltados, no caso, à ampliação do mercado interno. É claro que, para tanto, não estão desconectadas, em diversos aspectos, do contexto internacional, embora haja autonomia relativa no sentido de se propiciar o alargamento do mercado interno, como parece indicar a realidade brasileira a partir do governo Lula da Silva.

9. Disponível em: www.ibge.gov.br/home/estatistica/indicadores/pib/defaultcnt. shtm. Acesso em: 15/5 /2014. 
10. Disponível em: www.ibge.gov.br/home/estatistica/indicadores/pib/defaultcnt. shtm. Acesso em 15/5/2014.

11. Sobre o tema, ver Crespo e Gourovitz (2002). A vertente quantitativa é bem expressa por Rocha (2007).

12. Segundo a Pesquisa Nacional por Amostra de Domicílios (PNAD)/IBGE, extrema pobreza é o percentual de pessoas na população com renda per capita inferior à extrema pobreza, entendida como estimativa de valor para uma cesta de alimentos com o mínimo de calorias necessárias, segundo a FAO e a Organização Mundial de Saúde (OMS). Taxa de pobreza é o percentual de pessoas na população total com renda domiciliar per capita inferior à linha de pobreza. Alinha de pobreza aqui considerada é o dobro da linha de extrema pobreza.

13. Como se sabe, o Programa Bolsa Família é caracterizado por condicionalidades, isto é, compromissos que a família beneficiária deve cumprir: comprovação de vacinação dos filhos, acompanhamento da saúde da mulher, comprovação da frequência escolar, participação nos serviços de convivência do Programa de Erradicação do Trabalho Infantil etc. Por sua vez, o Estado deve prover serviços de assistência, saúde e educação. Ver http://www.mds.gov.br/bolsafamilia/condicionalidades. Acesso em $15 / 5 / 2014$.

14. O BPC dá direito ao recebimento de um SM aos idosos e deficientes físicos que possuam renda de até um quarto deste salário.

15. Disponível em: http://www.portaltransparencia.gov.br/PortalTransparenciaPesquisaAcaoUF.asp codigoAcao $=8442 \&$ codigoFuncao $=08 \&$ NomeAcao $=$ Transfer $\% \mathrm{E}$ Ancia + de+Renda+Diretamente+\%E0s+Fam \%EDlias+em+Condi $\% E 7 \% E 3$ $\mathrm{o}+\mathrm{de}+$ Pobreza+e+Extrema + Pobreza+\%28Lei+n $\%$ B A+10\%2E $836 \% 2 \mathrm{C}+\mathrm{de}$ $+2004 \% 29$ \&Exercicio $=2013$. Acesso em 20/5/2013.

16. Ver, nesse sentido, diversas publicações do Le Monde Diplomatique Brasil (diplomatique.uol.com.br/). Ver especificamente o artigo "O Cidadão Pode Contar com o Quê?", de Aldaíza Sposati, de 1 de fevereiro de 2011, e "Políticas Sociais como política de Estado", de Francisco Fonseca e Cristiane Leite, de 1 novembro de 2009.

17. Deve-se notar o esforço do governo federal em inserir na Previdência, por meio de contribuição, os setores informais da economia. Isso se dá pelo estímulo e legalização dos contribuintes individuais, que trabalham "por conta própria" ou prestam serviços diversos sem qualquer formalização.

18. Saldo previdenciário é o valor da diferença entre a arrecadação líquida (recebimentos próprios menos transferências a terceiros) e os benefícios previdenciários pagos. Saldo operacional é o valor da diferença entre o total de recebimentos e o total de pagamentos.

19. APrevidência do setor público é mais complexa. Na União, em termos operacionais e de saldo previdenciário ocorre algo não muito diferente do setor privado. No caso da União, há a cobrança de $11 \%$ dos ativos, complementada pelo Tesouro Nacional, sendo este um sistema recente, surgido a partir de 1990. Já estados e municípios têm regimes variados. O total de funcionários cobertos chegou a mais de 9 milhões em 2010 sendo pouco mais de 2 milhões na União, segundo o Anuário da Previdência Social Deve-se notar a recém-aprovada lei que institui o Regime Complementar Privado dos funcionários públicos federais.

20. Ainda que não idêntica e não obrigatoriamente no mesmo marco de suas conclusões, esta é a interpretação que faz jus a Werneck Vianna (2006).

DADOS - Revista de Ciências Sociais, Rio de Janeiro, vol. 58, nº 1, 2015 


\section{REFERÊNCIAS BIBLIOGRÁFICAS}

ANTUNES, Ricardo. (1995), Adeus ao Trabalho? São Paulo, Cortez.

BALTAR, Paulo E. de Andrade et al. (2010), “Moving Towards Decent Work. Labour in the Lula Government: Reflections on Recent Brazilian Experience". Working Papers, no 9, Global Labour University. Disponível em http:/ / www.global-labour-university.org/fileadmin/GLU_Working_Papers/GLU_WP_No.9.pdf. Acesso em $16 / 10 / 2011$

BANCO CENTRAL DO BRASIL. (2010), Indicadores Econômicos Consolidados. Disponível em http:/ / www.bcb.gov.br/?INDECO. Acesso em 2/11/2010.

BARROS, Ricardo Paes de; HENRIQUES, Ricardo; MENDONÇA, Rosane. (2001), “A Estabilidade Inaceitável: Desigualdade e Pobreza no Brasil". Texto para Discussão, no 800. Rio de Janeiro, Ipea.

CAMARGO, José Márcio. (1996), Flexibilidade do Mercado de Trabalho no Brasil. Rio de Janeiro, FGV Editora.

CRESPO, Antonio Pedro; GOUROVITZ, Elaine. (2002), “A Pobreza como Fenômeno Multidimensional". RAE Eletrônica, vol. 1, no 2. Disponível em http://www.scielo.br/pdf/raeel/v1n2/v1n2a03.pdf. Acesso em 20/11/2010.

EVANS, Peter. (1995), Embedded Autonomy, States and Industrial Transformation. Princeton, Princeton University Press.

IBGE (Instituto Brasileiro de Geografia e Estatística). Disponível em http://www. ibge.gov.br/home/mapa_site/mapa_site.php\#indicadores. Acesso em 1/11/2010.

IPEA (Instituto de Pesquisa Econômica Aplicada). IPEADATA. Disponível em http://www.ipeadata.gov.br/ipeaweb.dll/ipeadata?593150500. Acesso em $01 / 11 / 2010$.

MATTOSO, Jorge. (1995), A Desordem do Trabalho. São Paulo, Scritta.

OFFE, Claus. (1991), Trabalho e Sociedade. Problemas Estruturais e Perspectivas para o Futuro da Sociedade do Trabalho (vols. I e II). Rio de Janeiro, Edições Tempo Brasileiro.

PASTORE, José. (1998), O Desemprego tem Cura? São Paulo, Makron Books.

POCHMANN, Marcio. (2011), “Políticas Sociais e Padrão de Mudanças no Brasil durante o Governo Lula". SER Social, vol. 13, no 28, pp. 12-40.

QUEIROZ, Silvana et al. (2010), Evolução dos Programas Federais de Transferência de Renda (PBF e BPC) no Brasil e nos Estados do Nordeste - 2004-2009. Disponível em http:// www.abep.nepo.unicamp.br/encontro2010/docs_pdf/eixo_1/ abep2010_2557.pdf. Acesso em 1/11/2010.

RIFKIN, Jeremy. (2004), O Fim dos Empregos. São Paulo, Makron Books.

ROCHA, Sônia. (2007), Pobreza no Brasil: Afinal, do que se Trata? (3a ed.). Rio de Janeiro, FGV Editora.

SANTOS, Wanderley Guilherme dos. (2006), Horizontes do Desejo. (2a ed.). Rio de Janeiro, FGV Editora. 
SEN, Amartya K. (2000), Desenvolvimento como Liberdade. São Paulo, Companhia das Letras.

STIGLITZ, Joseph. (2003), Os Exuberantes Anos 90. São Paulo, Companhia das Letras.

WERNECK VIANNA, Luiz. (2006), Esquerda Brasileira e Tradição Republicana: Estudos de Conjuntura sobre a Era FHC-Lula. Rio de Janeiro, Revan. 
RESUMO

A Macrodinâmica Social Brasileira: Mudanças, Continuidades e Desafios

Procura-se neste artigo retratar o Brasil contemporâneo a partir de dados agregados sobre trabalho, emprego, renda, pobreza e desigualdade, buscando estabelecer a evolução recente de sua macrodinâmica social. Para tanto, analisa-se o papel do aumento exponencial do emprego; da redução do desemprego e da informalidade; da valorização real do salário mínimo e do aumento da média salarial; do fortalecimento da Previdência Social e dos programas sociais; e do recuo da extrema pobreza. Tais dados denotam comparativamente que, enquanto o governo Cardoso voltou-se ao investimento privado, restrição monetária e fiscal e reformas a um Estado menor (um dos sentidos de "moderno"), no governo Lula da Silva houve outra perspectiva de "modernização": o reforço da capacidade estatal por "autonomia inserida". Conclui-se que o desafio "modernizador" permanece voltado à redistribuição da riqueza, à criação do Estado de Bem-Estar efetivo e à inserção soberana no cenário internacional.

Palavras-chave: trabalho; renda; desigualdade; política social; desenvolvimento

\section{ABSTRACT \\ The Brazilian Social Macrodynamic: Changes, Continuities and Challenges}

Contemporary Brazil is portrayed based on aggregate data on work, employment, income, poverty, and inequality, seeking to establish the recent of the social macrodynamic. To this end, the authors analyze role of the exponential increase of employment, the reduction of unemployment and informalization; real minimum wage increases and the rise of average salaries, the strengthening of Social Security and social programs; the retreat of extreme poverty. This set of data comparatively indicates that, while the Cardoso government turned toward private investment, monetary and fiscal restriction, and state reform (in the "modern" sense of decreasing its size), in the Lula government another perspective of "modernization": the reinforcement of state capacity to achieve "embedded autonomy". It concludes that the challenge of modernization is still guided towards redistribution of wealth, the creation of an effective Welfare State and sovereign insertion in the international arena.

Keywords: labor; income; inequality; social policy; development 


\author{
RÉSUMÉ \\ Macro-dynamique Sociale Brésilienne: Transformations, Continuités et \\ Défis
}

On cherchera ici à brosser un portrait du Brésil contemporain à partir de données compilées sur le travail, l'emploi, le revenu, la pauvreté et les inégalités, dans le but de mettre en lumière les évolutions récentes de la macro-dynamique sociale du pays. À cette fin, on analysera le rôle de l'augmentation exponentielle de l'emploi; de la réduction conséquente du chômage et du travail informel; de l'augmentation réelle du salaire minimum et du salaire moyen; du renforcement de la Sécurité sociale et des programmes sociaux; ainsi que du recul de l'extrême pauvreté. Comme nous le montrent ces données, tandis que le gouvernement Cardoso privilégiait l'investissement privé, la compression monétaire et fiscale, et des réformes vers moins d'État (l'un des sens de "moderne"), le gouvernement Lula da Silva a quant à lui ouvert une autre perspective de "modernisation": le renforcement de la capacité de l'État en vue d'une "autonomie intégrée". On en conclut que le défi "modernisateur" est axé sur la redistribution du revenu, la création d'un État-providence effectif et l'intégration souveraine à la scène internationale.

Mots-clés: travail; revenu; inégalités; politiques sociales; développement

\title{
RESUMEN
}

La Macrodinámica Social Brasileña: cambios, continuidades y desafíos

Este artículo busca diseñar un retrato del Brasil contemporáneo a partir de datos agregados sobre trabajo, empleo, renta, pobreza y desigualdad, con el objetivo de establecer la evolución reciente de su macrodinámica social. Para ello, se analiza el papel del incremento exponencial del empleo; de la reducción del paro y de la informalidad; de la valorización real del sueldo mínimo y del aumento de la media salarial; del fortalecimiento de la Seguridad Social y de los programas sociales; y del retroceso de la pobreza extrema. Estos datos indican comparativamente que, mientras el gobierno Cardoso privilegió la inversión privada, la restricción monetaria y fiscal, y reformas hacia un Estado menor (unos de los sentidos de lo "moderno"), en el gobierno Lula da Silva hubo otra perspectiva de "modernización": el refuerzo de la capacidad estatal por "autonomía inserida". Finalmente, se concluye que el desafío "modernizador" sigue dirigido hacia la redistribución de la riqueza, la creación del Estado de bienestar efectivo y la inserción soberana en el escenario internacional.

Palabras clave: trabajo; renta; desigualdad; política social; desarrollo 